\title{
サルコイドーシスの肝肉芽腫の病理形態学的研究 一微細構造を中心に一
}

$\begin{array}{lll}\text { 関 } & \text { 孝一 } & \text { 南 雄三 } \\ \text { 河田 } & \text { 純男 } & \text { 垂井清一郎* }\end{array}$

要 旨：サルコイドーシス 24 例を対象に腹腔鏡検査を行ない, 肝肉芽腫の微細構造を中心に病 理形熊学的に検討した．腹腔鏡視診下の針生検で肝肉芽腫は20例，83\%の高率に検出され，直 視下生検の有用性が示された。肝肉芽腫は類上皮細胞, 形質細胞様の細胞, リンパ球，線維細 胞の 4 種類の細胞により構成される。類上皮細胞は大型，小型の単核類上皮細胞，多核巨細胞 の 3 種類に分類でさる。単核類上皮細胞は活発に生合成を営さ活動性細胞で, Golgi 装置, vacuole, 系粒体などが豊富で, 細胞膜の interdigitation 形成が特徵的である. 大型は小型に比 べより活動的と考えられる. lysosomeなど異物頜食所見を示さないことは興味深い.多核巨細 胞は大型単核類上皮細胞の fusionにより形成される所見を得た。形質細胞様の細胞は lysosomeをるつなど類上皮細胞と異なる細胞であり，両者の移行形と考点られる細胞は認めら れない。

索引用語：サルコイドーシス肝肉芽腫症肉芽腫類上皮細胞

はじめに

サルコイドーシスく以下サ>は原因不明の類上皮細 胞肉芽腫を形成する全身性疾患であって，肉芽腫は肝 のほか肺，眼，脾，リンパ節，皮唐，耳下腺，神経な どに形成される。

我々はサを対象に腹腔鏡検查，肝生検を行なってき た成績より，肝が肉芽腫を高率に検出できる臟器であ ることを知り，サの形態学的診断に腹腔鏡桧查が有用 であることを述べてきだ、㐻芽腫の微細構造につい てもリンパ節，脾，皮䖉などを対象とした研究はあ る3 8)か，肝を対象とした研究は少ない．

ここにサの肝病变につき腹腔鏡検查の意義と病理形 態面からの検討，とくに微細構造を中心に報告する。

症例

対象は腹腔鏡検查，肝生検を施行したサ24例である (Table 1).男11例，女13例で年齢は12歳から46歳，平 均年齢は25歳である。，サの診断は肺病変に加えて右鎖 骨下リンパ節病変, 眼病変, 皮度病変などから, 腹腔 鏡検查の時点で確定されている.

\footnotetext{
* 大阪大学第 2 内科
}

$<$ 受付日58年 8 月 1 日 $>$

\section{成 績}

\section{1. 臨床所見}

集団検診がサ発見の端緒となった症例が13例を占め る.自覚症状はないか軽微である (Table 1). $2 \mathrm{~cm}$. こえる肝腫大例は 20 例中 2 例 $(10 \%)$ ，脾腫大例は 20 例

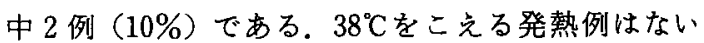
(Table 2). ツ反陰性例は18例中12例（67\%），1時間 值 $20 \mathrm{~mm}$ をこえる血沈促進例は16例中 4 例 (25\%) で ある、肝機能検査異常例は少なく，異常例もその程度 は軽微である (Table 3). 肝結核症と対比する目的で 自験例 9 例の臨床所見を Table 2,3 に併わせ揭げる.

\section{2. 肝表面所見}

肉芽腫結節は腹腔鏡視診下に円形ないし棈円形の， 帯黄白色ないし灰白色の斑点としてみ兄, 径0.5から $2 \mathrm{~mm}$ 大のすのが多い.(Fig. 1, left). 大形で不整形で 2 コ以上の肉芽腫が融合した形の径 $10 \mathrm{~mm}$ をこえる大結 節もみ觉る (Fig. 1, right). 肝表面は平滑で，一部の 結節は肝表面からわずかに盛上ってみえる，肉芽盾結 節の数は数コのものから肝表面一面に散在するものま である、結節の分布はきまったものはないが，肝円靯 帯付着部近傍の肝表面に観察しやすい，結節は一般に 新鮮結節は帯黄色に，陳旧結節は灰白色に，症痕化し 
た結節は白色陥凹としてみえる。

腹腔鏡下の肉芽腫結節の視診率は，腹腔鏡検查の時 点でサの診断が知られていることすあり，注意深く観 察すると程度の差こそあれ全症例に結節が視える様に おるわれる。しかしこの中には肝表面像のみでは肉芽 腫結節と断じえないものが含まれる．訮表面に線維性

Table 1. Hepatic Granulomata in Sarcoidosis (24 Cases)

\begin{tabular}{|c|c|c|c|c|}
\hline Case & & & Chest X-P & Extrathoracic Lesion \\
\hline 1 & $14 F$ & fever, eye lesion & $B H L+L$ & r-scalen node, eye \\
\hline 2 & $20 \mathrm{M}$ & mass exam & $\mathbf{L}$ & \\
\hline 3 & $19 \mathrm{~F}$ & mass exam & L & r-scalen node \\
\hline 4 & $18 \mathrm{~F}$ & mass exam & $B H L+L$ & $r$-scalen node \\
\hline 5 & $15 \mathrm{M}$ & mass exam & $\mathrm{BHL}+\mathrm{L}$ & $r$-scalen node \\
\hline 6 & $28 \mathrm{~F}$ & mass exam & $B H L+L$ & \\
\hline 7 & $27 \mathrm{~F}$ & eye lesion & $\mathrm{BHL}$ & eye \\
\hline 8 & $25 \mathrm{M}$ & parotid lesion & BHL & r-scalen node, skin, parotid \\
\hline 9 & $28 M$ & cough, sputum & $\mathrm{BHL}$ & r-scalen node, eye \\
\hline 10 & $22 \mathrm{M}$ & cough & $\mathrm{BHL}+\mathrm{L}$ & r-scalen node \\
\hline 11 & $30 \mathrm{~F}$ & mass exam & BHL+L & r-scalen node \\
\hline 12 & $12 M$ & fever, cough & $\mathrm{BHL}+\mathrm{L}$ & r-scalen node, eye \\
\hline 13 & $21 \mathrm{~F}$ & mass exam & $\mathrm{BHL}+\mathrm{L}$ & \\
\hline 14 & $17 \mathrm{M}$ & mass exam & BHL & r-scalen node \\
\hline 15 & $23 \mathrm{~F}$ & mass exam & BHL+L & r-scalen node \\
\hline 16 & $25 \mathrm{~F}$ & mass exam & BHL & r-scalen node \\
\hline 17 & $34 \mathrm{M}$ & mass exam & BHL & \\
\hline 18 & $25 \mathrm{M}$ & mass exam & $\mathrm{BHL}$ & \\
\hline 19 & $29 \mathrm{~F}$ & $\mathrm{BHL}$ & BHL & \\
\hline 20 & $25 M$ & mass exam & $B H L+L$ & r-scalen node \\
\hline 21 & $41 \mathrm{~F}$ & BHL & BHL & \\
\hline 22 & $38 \mathrm{~F}$ & parotid lesion & L & parotid \\
\hline 23 & $46 \mathrm{~F}$ & mass exam & BHL & \\
\hline 24 & $30 \mathrm{M}$ & mass exam & $\mathrm{BHL}$ & eye \\
\hline \multicolumn{5}{|c|}{ BHL : Bilateral Hilar Lymohadenopathy } \\
\hline
\end{tabular}

窥着を伴ならサは視ていない，慢性肝疾患の所見を伴 ならサも視ていない。

\section{3. 光㩆所見}

サ24例を対象に腹腔鏡視診下に径 $3 \mathrm{~mm}$ 大の Vim Silverman 改良針を用いて針生検を行なった。一部の 症例は肝表面の結節をねらって目標穿刺を行ない（清 永法)，また一部の症例は連続切片を作製して肉芽尰の 検出に努めた。 この様にして24例中20例の針生検肝組 織標本に肉芽連を観察した。肉芽尰の検出率は $83 \%$ と なる.

肉芽董はその周辺を線維細胞に取囲こまれ，肝実質 細胞と明瞭に区犃される (Fig. 2). その分布は門脈域

Table 2. Clinical Findings of Sarcoidosis and Tuberculosis

\begin{tabular}{lcc}
\hline & Sarcoidosis & Tuberculosis \\
Hepatomegaly $(>2 \mathrm{~cm})$ & $2 / 20(10 \%)$ & $4 / 9(44 \%)$ \\
Splenomegaly $(>2 \mathrm{~cm})$ & $2 / 20(10 \%)$ & $2 / 9(22 \%)$ \\
Fever $(>38 \mathrm{c})$ & $0 / 20(0 \%)$ & $5 / 9(55 \%)$ \\
\hline
\end{tabular}

Table 3. Laboratory Findings of Sarcoidosis and Tuberculosis

\begin{tabular}{lcc}
\hline & Sarcoidosis & Tuberculosis \\
Tuberculin Test, negative & $12 / 18(67 \%)$ & $1 / 7(14 \%)$ \\
BSR $(>20 \mathrm{~mm} /$ hour $)$ & $4 / 16(25 \%)$ & $7 / 9(78 \%)$ \\
GPT $(>40 \mathrm{U})$ & $2 / 19(11 \%)$ & $2 / 9(22 \%)$ \\
GOT $(>35 \mathrm{U})$ & $1 / 18(6 \%)$ & $3 / 7(43 \%)$ \\
ALP $(>10 \mathrm{KAU})$ & $2 / 19(11 \%)$ & $4 / 9(44 \%)$ \\
$\gamma$-Glob $(>2.0 \mathrm{~g} / \mathrm{dl})$ & $2 / 18(11 \%)$ & $3 / 7(43 \%)$ \\
\hline
\end{tabular}

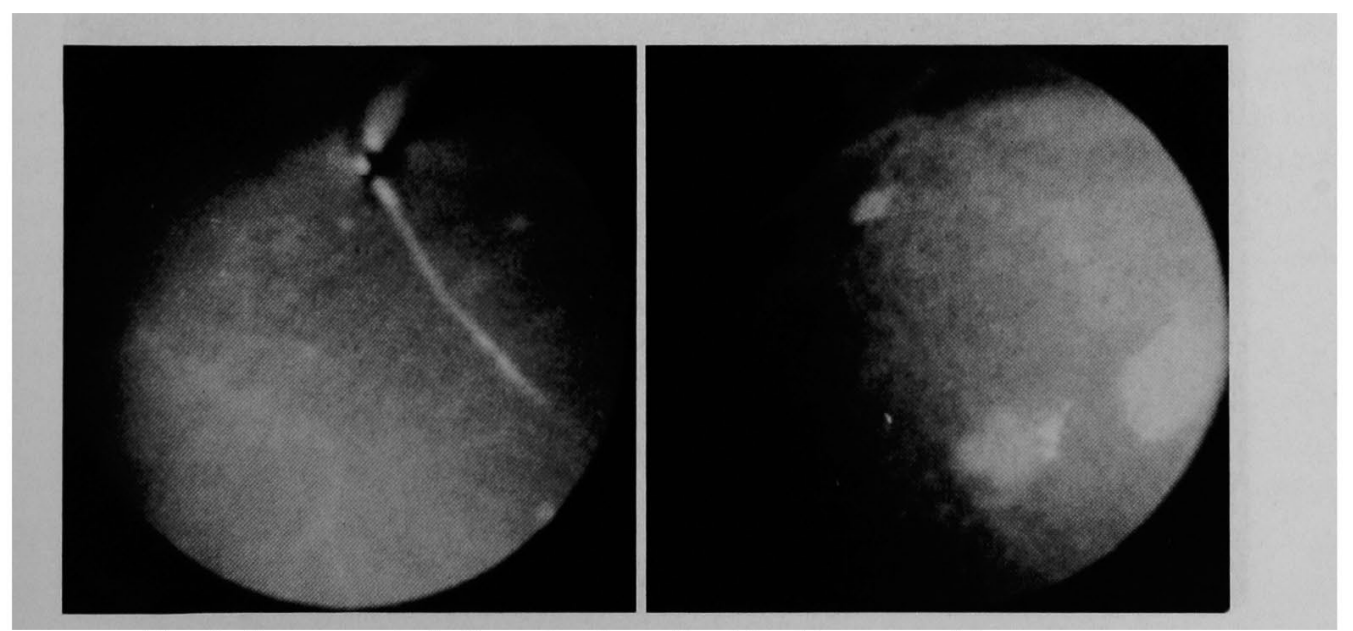

Fig. 1 Laparoscopic findings showing yellowish white spots of $0.5 \sim 1.0 \mathrm{~mm}$ in diameter scattered on the liver surface (left). Irregular shaped large spots are characteristic of sarcoidosis (right). 
近傍に位置するものが多い，その数は標本上に 1 コの ものから $25 \mathrm{~mm} \times 2 \mathrm{~mm}$ の標本上に 15 こを算えたるの まである”。類上皮細胞は棈円形ないし紡錘形の核を もち大形で明るい，核小体は明瞭である．細胞質は広 く好酸性に染まる。. Langhans 型あるいは異物型の巨 細胞が高頻度にみられる。乾酪壊死を併なら所見はな い.

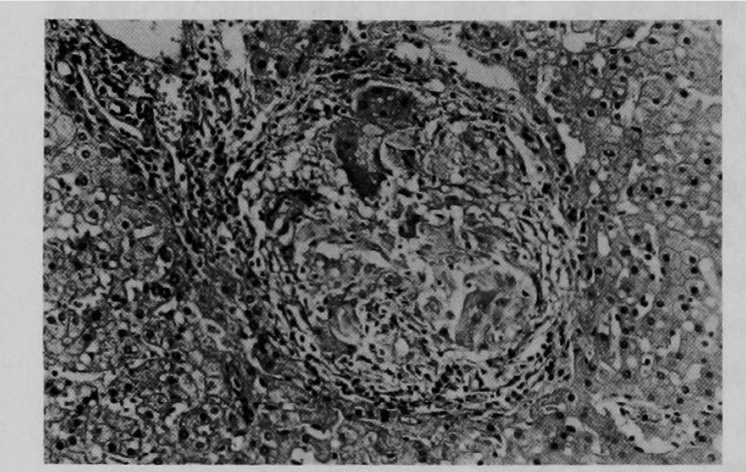

Fig. 2 Liver biopsy showing noncaseating epithelioid cell granuloma which is demarcated sharply from the surrounding hepatocytes. H.E. $\times$ 100

\section{4. 電㩆所見}

サ10例に肉芽腫の微細構造を観察した，肝標本はs. collidine buffered $2 \% \mathrm{OsO}_{4}$ で単独固定し, 酷酸ウラ ン，酷酸鉛の二重染色を行なって観察に供した，肉芽 腫を構成する細胞は類上皮細胞, 形質細胞様の細胞, リンハ・球，線維細胞の 4 種類の細胞を算える。

(1) 類上皮細胞

類上皮細胞は結節内に free の状態で存在する。細胞 膜は偽足様突起を形成し, 隣接する類上皮細胞々 interdigitation を形成して結合する(Fig. 3－5).tight junctionをるっ結合する所見はない，長い為足様突 起がからみ合って高度の interdigitation 形成する 所見すある（Fig. 7). 我々は類上皮細胞を大型単核類 上皮細胞，小型単核類上皮細胞，多核巨細胞の 3 種類 にわけてその微細構造をのべる。

a. 大型単核類上皮細胞 (Fig. 3, 4)

肉芽庫の主要構成細胞でもっとも数多く観察でき る. 核は円形のbのが多く核膜は平滑で核小体は明膫 である，細胞質は広く小器官は豊富で密に集合する。 多数の釆粒体, 小胞体の空胞化, Golgi 装置の発達が特 徽で coated vesicle, pinocytotic vesicle \&数多

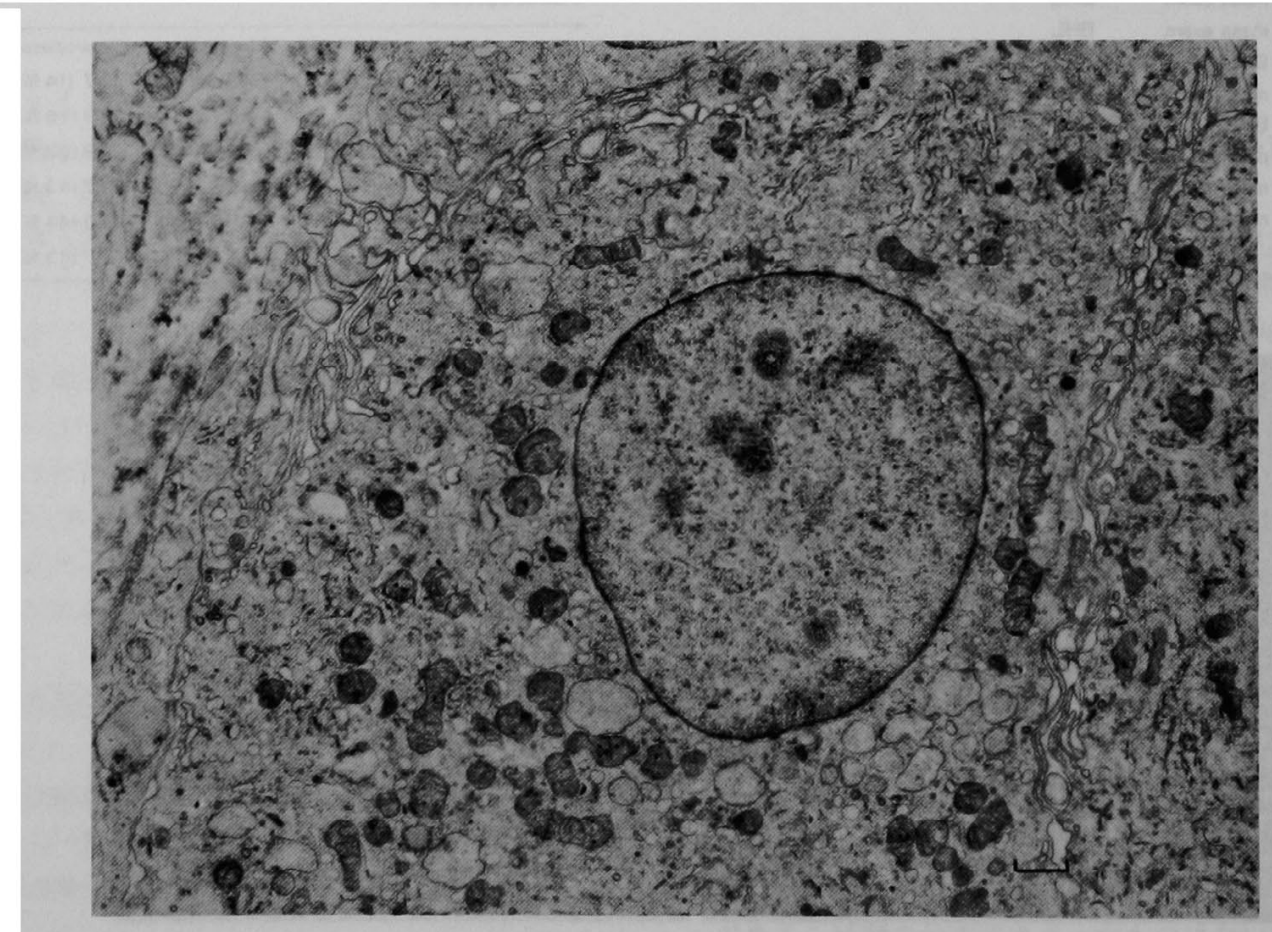

Fig. 3 Large mononuclear epithelioid cell showing abundant cytoplasmic organelles. Interdigitating cytoplasmic processes is characteristic of epithelioid cells. 


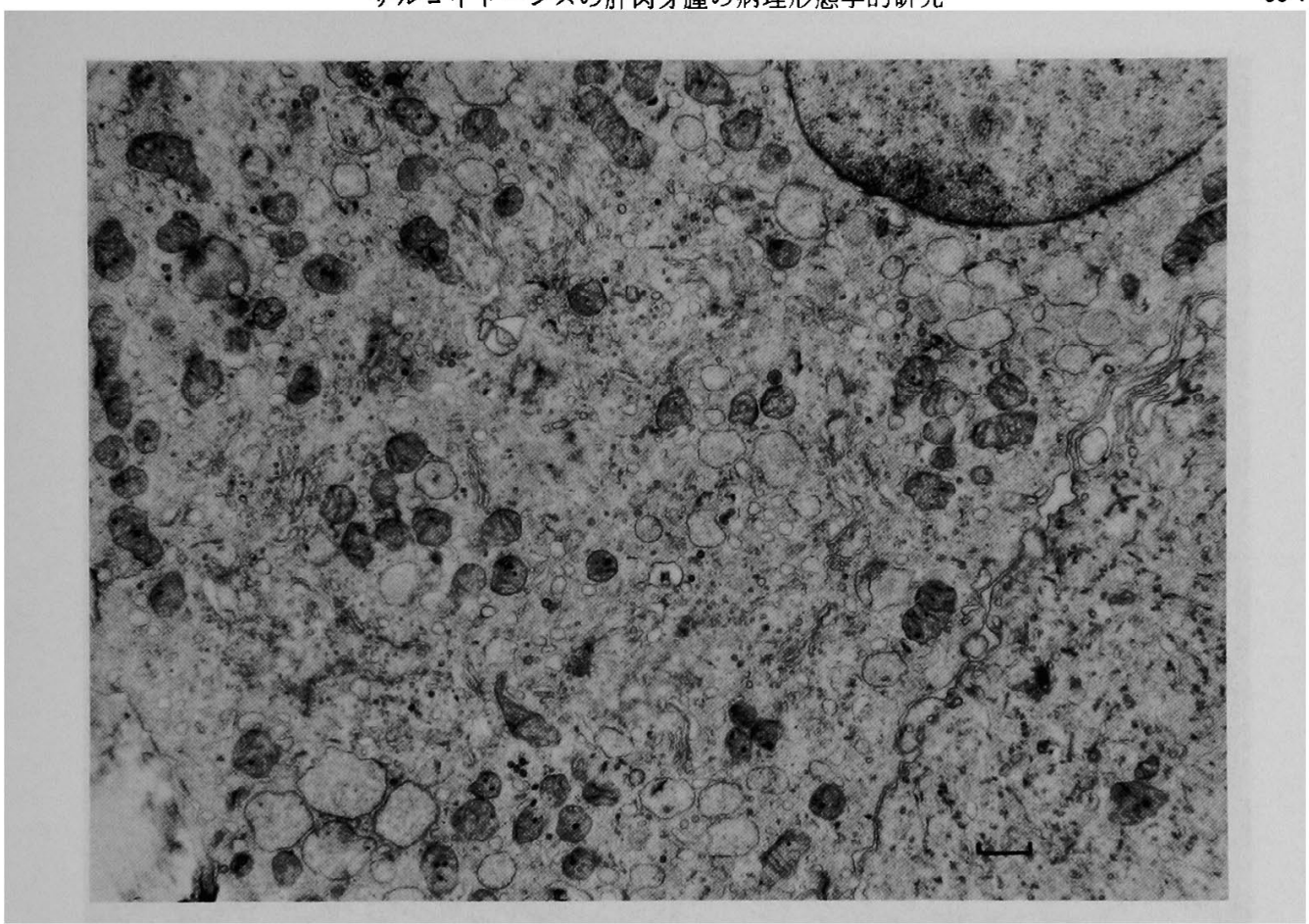

Fig. 4 Higher magnification of Fig. 3 showing large amounts of Golgi apparatus and dense vacuoles in the cytoplasm. Lysosomes and glycogen particles are absent.

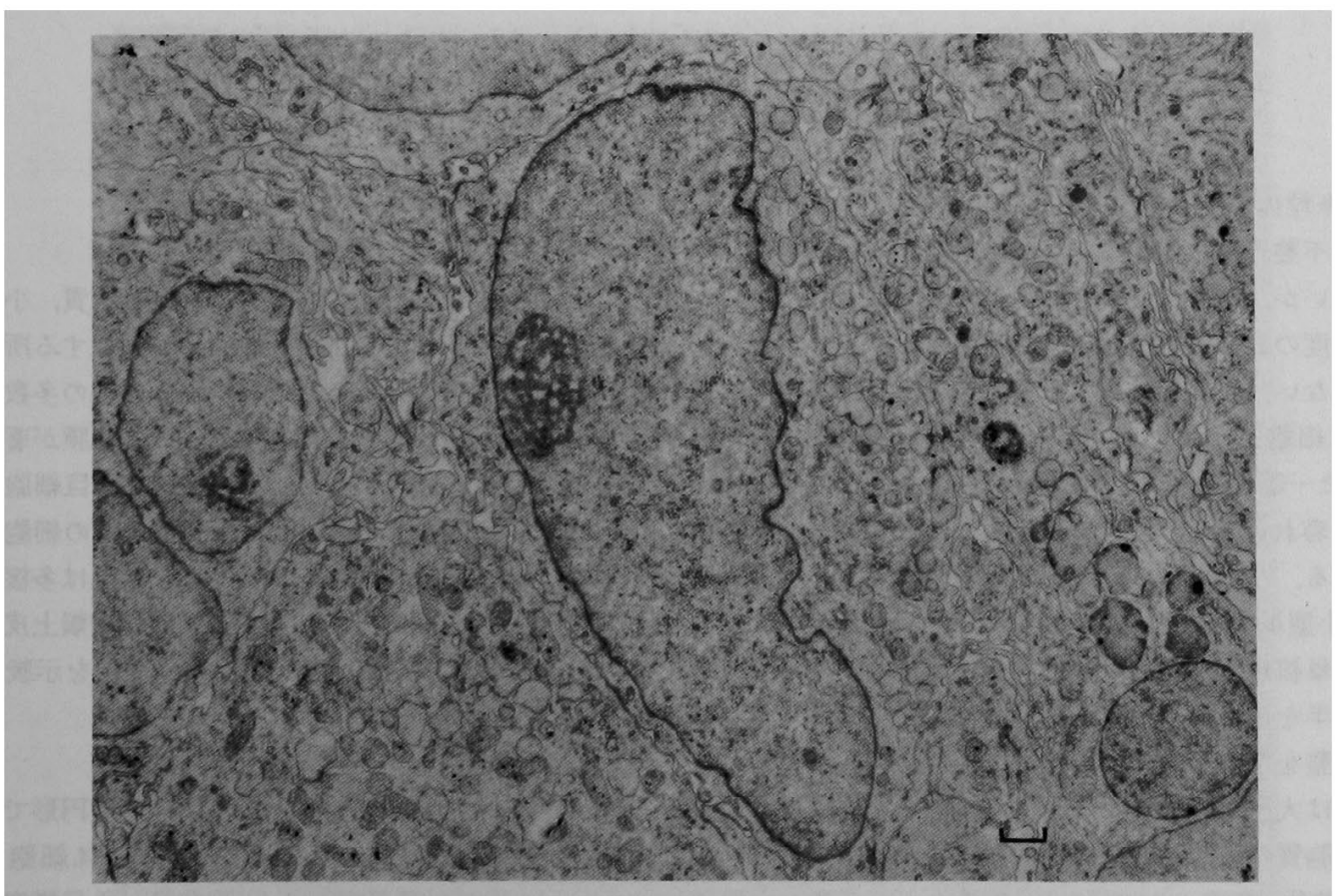

Fig. 5 Small mononuclear epithelioid cell showing irregular shaped nucleus with prominent nucleolus. The size of mitochondria and vacuoles is smaller than that of large ones. 


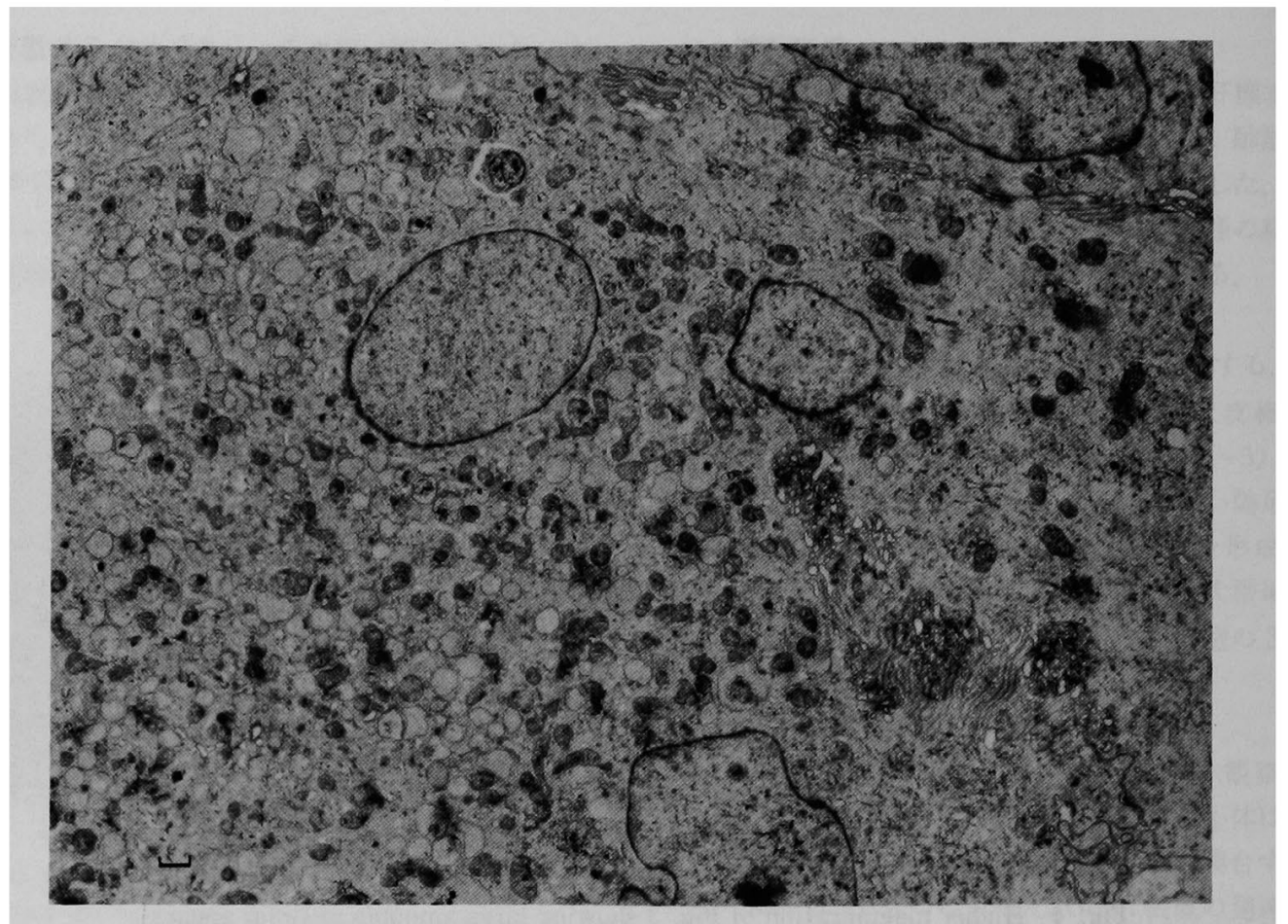

Fig. 6 Multinuclear giant cell containing three nuclei arranged around the peripheri of the cytoplasm. The features of cytoplasm have the similar appearance of those of large mononuclear epithelioid cells. As seen in the right lower of this figure, interdigitating cytoplasmic menbrane interwave deeply into cytoplasm and cytoplasm of both side of the interdigitating cytoplasmic processes shows different features each other

れる. 系粒体は円形で径 $0.5 \sim 1.0 \mu$ 前後のものが多い. 空胞は不整円形で $1 \boldsymbol{\mu}$ 前後の比較的揃った大きさのも のが多いが,なかに $1.5 \mu$ をこえる大きなるのもあり，

電子密度の低い内容をるつ. lysosomeなどの異物領食 所見はない.glycogen 顆粒は認めない. 一部の類上皮 細胞は細胞質内に多量の粗面小胞体を容れる (Fig. 8). また一部の類上皮細胞は多量の filamentous structure を容れ(Fig. 9)類上皮細胞の変性所見の一つと考 えられる。

b. 小型単核類上皮細胞 (Fig. 5)

大型単核類上皮細胞より数少ない。核は紡鉎形で細 胞の大半を占める. 核膜は平滑なるのと一部が軽度の 凹凸不整を示すむのとがある（Fig. 5).細胞質は㹟く 小器官は大型単核類上皮細胞にくらべるとやや数少な い. 細胞質の明暗の程度に大型と小型の間に差異はな い. 米粒体, 空胞ともに径 $0.5 \mu$ 前後のものが多く大型 単核類上皮細胞にくらべより小型である. 細胞膜の媯 足様突起の数や interdigitation の程度もまた大型単
核類上皮細胞にくらべ軽度である。

c. 多核巨細胞 (Fig. 6)

円形の核と広い細胞質をむち, 核, 細胞質, 小器官 はいずれる大型単核類上皮細胞とよく類似する所見を 示寸. 細胞膜も大型単核類上皮細胞と同様の多数の偽 足様突起を形成する.巨細胞のなかに細胞膜が著明な interdigitationを形成して細胞の周辺より巨細胞のな かに深く入り込み, interdigitationの両側の細胞質か; 相異なる性状を示するのがある。この所見は多核巨細 胞が単核類上皮細胞, 拈そらくは大型単核類上皮細胞 が fusionすることにより形成されることを示唆する 所見と考学られる。

(2) 形質細胞様の細胞 (Fig. 10)

類上皮細胞にくらべ数少ない，核は不整円形で核小 体は不明瞭である。形質細胞様の細胞は細胞質に lysosome 顆粒が存在すること, 細胞膜が偽足様突起を もたないこと，小器官が数少なく粗に分布することな どの点で類上皮細胞と相異する，糸粒体はより大形で 


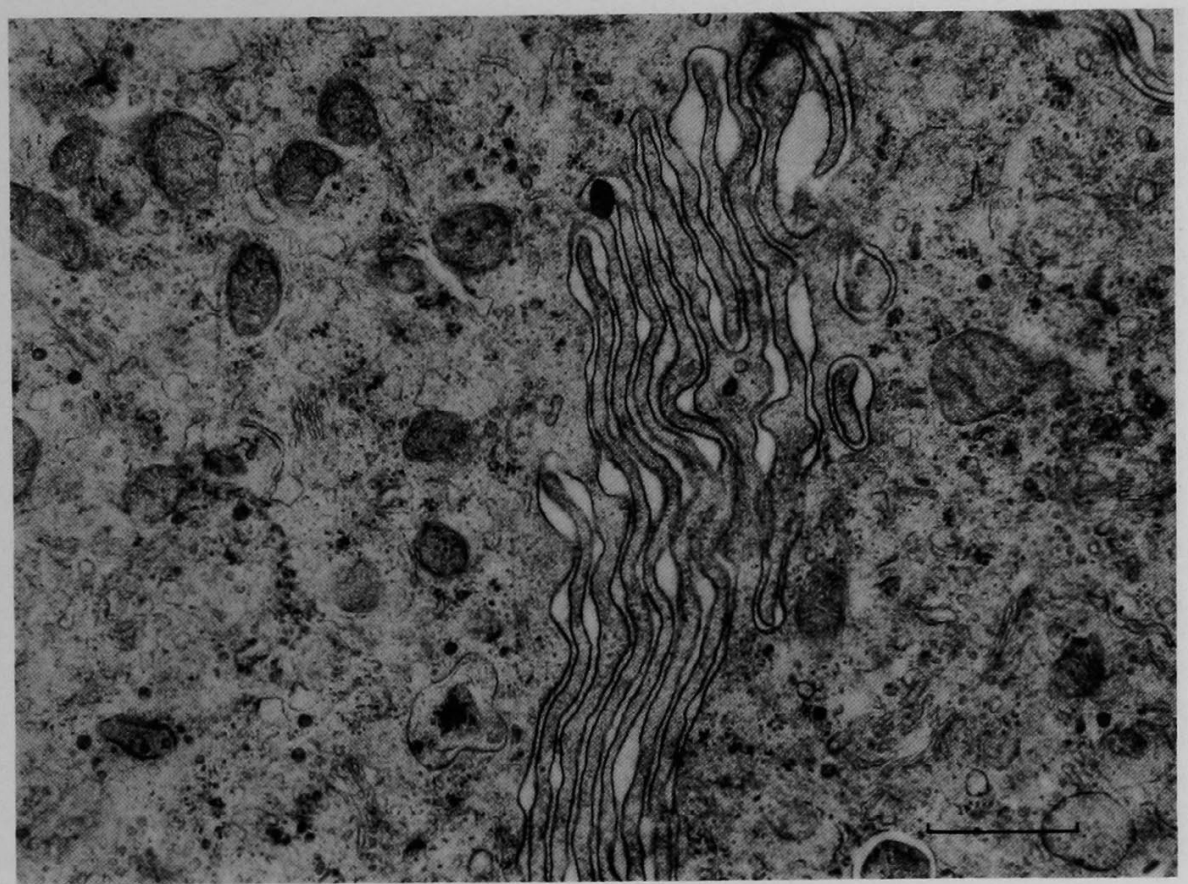

Fig. 7 Between adjuscent epithelioid cells elongated cytoplasmic processes has developed marked interdigitating processes. Tight junction is not seen.

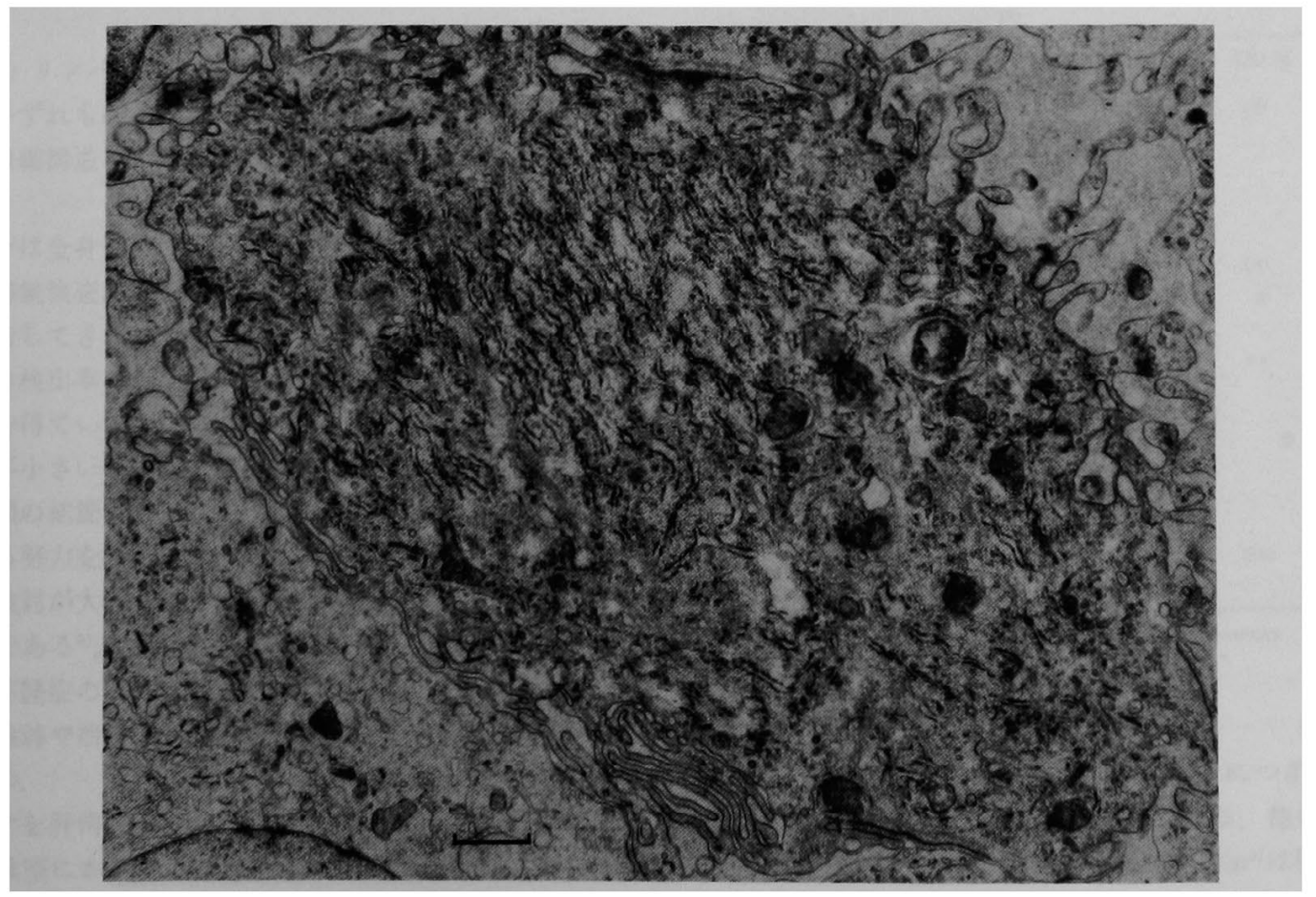

Fig. 8 Epithelioid cell showing abundant rough-surfaced endoplasmic reticulum in the cytoplasm. 


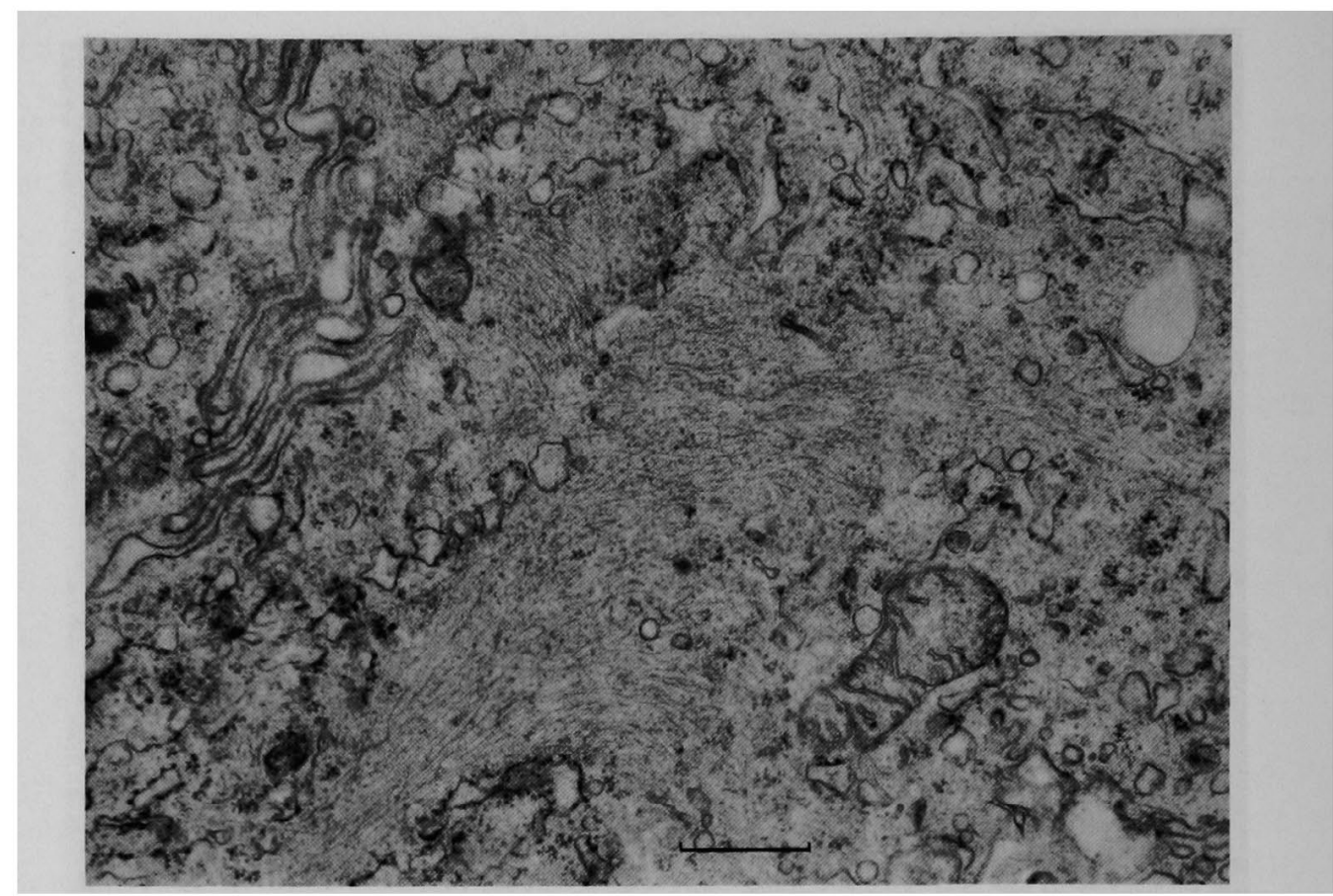

Fig. 9 Epithelioid cell showing abundant filamentous structure in the cytoplasm.

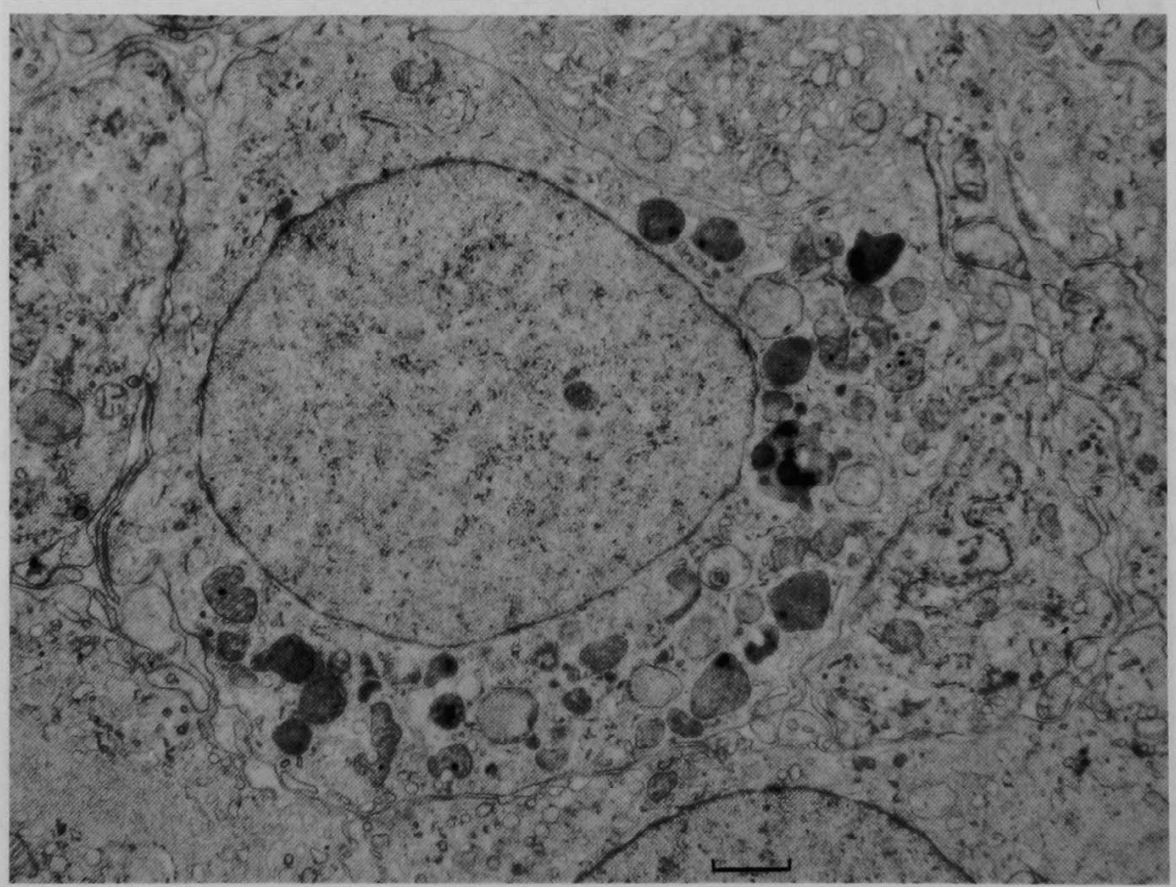

Fig. 10 Histiocyte-like cell showing different cytoplasmic features from those of epithelioid cells. Secondary lysosomes are shown in the cytoplasm. 


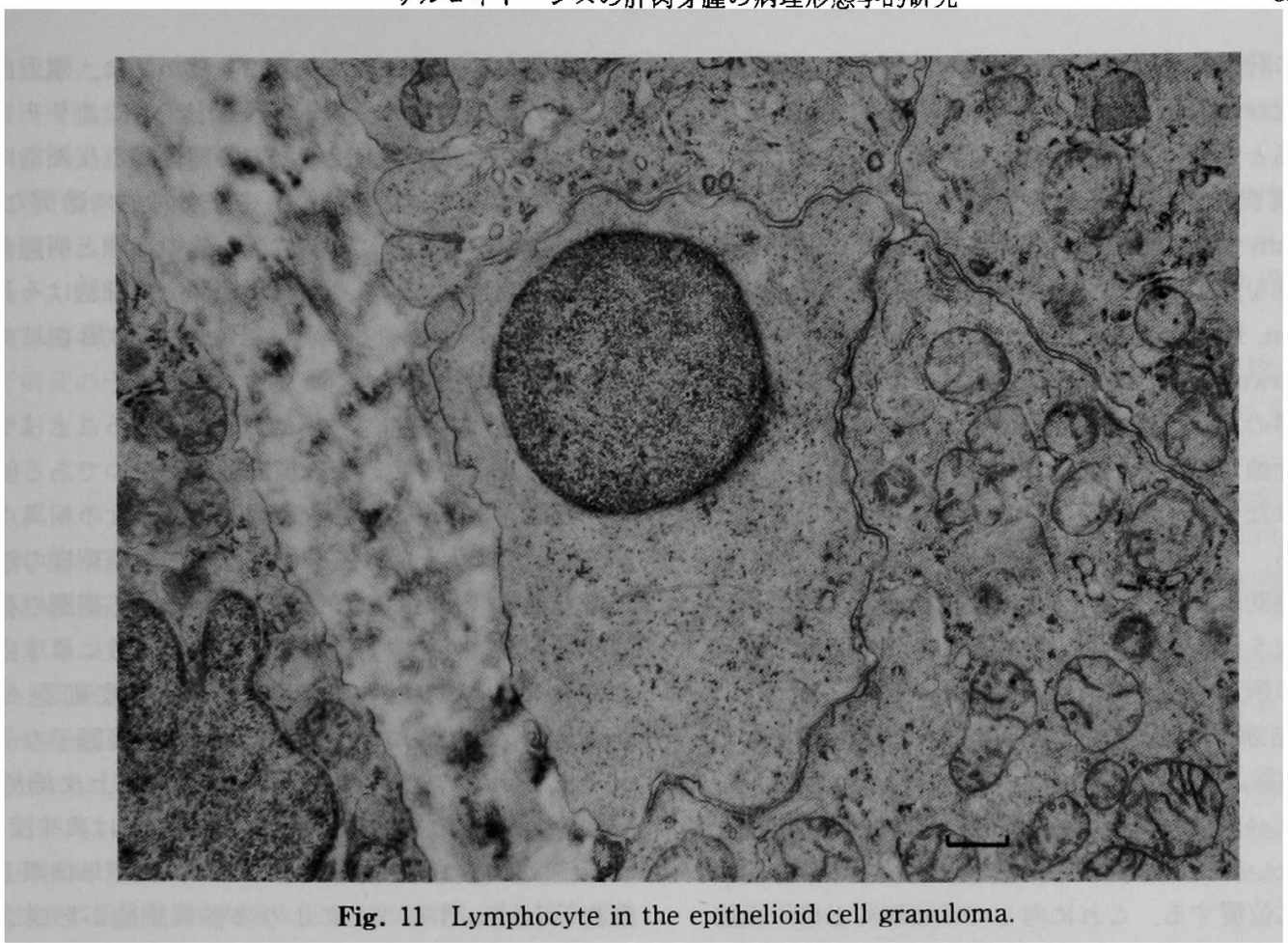

不整形である. Golgi 装置や空胞の数も少ない（Fig. $10)$.

(3)リン八球と線維細胞 (Fig. 11)

いずれる肉芽腫結節に特有な所見はない、リンパ球

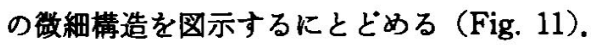

\section{考按}

サは全身性の肉芽遁性病変で，その形態学的診断に 腹腔鏡検㚗, 肝生検が有用であることはつとに我々が 報告してきたところである，生検肝標本における肉芽 睡の検出率はサを対象とした我々の検討から83\%の高 率を得ている，針生検標本は開腹生検にくらべ採取標 本が小さいららみはあるが，我々は腹腔鏡視診下に肝 表面の結節を目標穿刺するなどの方法で，検出率を高 める努力をしている.より長い標本の採取と連続切片 の検討が大切であることはすでに強調されているとこ ろである9!。腹妧鏡検査はその簡便性と安全性から肝 肉芽隀症の初期診断に有用であるとともに，臨床経過 の追跡や治療効果の判定に反復して検索しらる利点を कつ.

サを肝肉芽腫症の観点からみると，大阪大学第 2 内 科教室に括ける腹腔鏡娭查 3,650 例中生検肝標本に肉 芽腫を検出した症例は57例にのぼる，その原因疾患の らちわけを Table 4 に揭げる. サの20例がもっとも高
Table 4. Hepatic Granulomata Demonstrated in 3.650 Needle Biopsies

\begin{tabular}{|c|c|c|}
\hline Total & 57 cases & $100 \%$ \\
\hline Tuberculosis & 9 & 16 \\
\hline miliary & 8 & \\
\hline tuberculoma & 1 & \\
\hline Leprosy & 1 & \\
\hline Syphilis & 1 & \\
\hline Sarcoidosis & 20 & 35 \\
\hline Primary Biliary Cirrhosis & 5 & 9 \\
\hline Drug & 1 & \\
\hline Autoimmune Diseases & 6 & 11 \\
\hline Plasma Cell Hepatitis & 2 & \\
\hline Polyarteritis Nodosa & 1 & \\
\hline Polymyositis & 1 & \\
\hline Hodgkin's Disease & 1 & \\
\hline Multiple Sclerosis & 1 & \\
\hline Association obscure & 14 & 25 \\
\hline Fever of Unknown Origin & 4 & \\
\hline
\end{tabular}

Second Deportment of Internal Medicine, Osaka University Medical School

頻度で $35 \%$ を占め, 肝結核症の 9 例がこれにつぎ $16 \%$, 原発性胆汁性肝硬変症 5 例 $9 \%$ の順となる。他の疾患 は数少ないすのである。ちなみに Klatskin"は肝肉芽 隀症を大をく，1．全身性肉芽睡疾患，2．肝疾患， 3 . その他に分類している. Irani ${ }^{10)}$ は欧米の報告1,008例 
をもとに肝肉芽腫症のうちわけとての頻度を, サ39\%， mycobacterial 15\%, 肝疾患 $24 \%$ ，乙の他 $8 \%$ ，原因 不明 $14 \%$ とまとめている。

腹腔鏡視診下にサの肉芽腫結節はその多くが径 0.5 2mm 大の結節としてみえる. Beck ${ }^{11)}$ はサ肝の腹 腔鏡所見を, Miliare Lebersarkoidose, Konglomeratknötchen, Knotige Lebersarkoidose, Konfluierende Lebersarkoidose の 4 型に分類している。一般に大型 で不整形の肉芽腫結節はサの特徵とされる の肝表面像からサを他の肉芽腫病変と鑑別することは 容易ではない，診断確定に肝生険が不可欠となるゆ六 んである。サ他の肉芽腫病变，とくに肝結核症と鑑 別する補助所見の一つとして，苦は肝表面に線維性㾤 着を伴なら症例がないことから，我々は肝表面の線維 性瘜着の所見をみればサは否定的と断じている。なお 肉芽腫結節との鑑別が必要となる非肉芽腫病変とし て, 脂肪肝, 転移性肝癌, リンパ腫などが挙げられる.

光顕レベルにおけるサの肉芽腫結節は，乾酪罗死を 伴なわない類上皮細胞肉芽腫が特徵で，主として門脈 域周辺に位置する。これに対して乾酪罗死と格子線維 の破壊は肝結核症の特改で, 肝実質内あるいは小葉中 心部に位置することも特徴とされる ${ }^{12)}$. しかし乾酪壊 死を併なわない肝結核症す多い，結核症の診断は肉芽 腫に結核菌を証明することで確定する，生検肝標本の 結核菌染色で45\%に，培堢で57\%に，染色と培養を併 わせ実施することで $61 \%$ に結核菌を証明する ${ }^{13)}$ との報 告もあるが，針生検の小標本で結核菌を証明すること は容易でなく，自験例で結核菌を証明しえたのは 8 例 中 2 例にとどまる。

サの肝肉芽腫結節はその微細構造上, 類上皮細胞, 組織球様の細胞, 線維細胞, リンパ球の 4 種頪の細胞 から構成される。類上皮細胞は采粒体の增加，小胞体 の空胞化，Golgi 装置の発達などから旺盛な生合成を 営む活動性細胞と考えられる，その機能を免疫クロブ リンの産生と結びつけて論じるすのもある5). 我々は 類上皮細胞を大型単核類上皮細胞，小型単核類上皮細 胞, 多核巨細胞の 3 種類に大別している. 大型と小型 の分類は純粋に微細構造面からの分類であって，細胞 の大きさ，核の形，小器官の密度，系粒体と空胞の大 きさ, Golgi 装置の発達の程度に差異がある.これらの 差異から大型単核類上皮細胞は小型単核類上皮細胞に くらべょり活動的に機能を営む細胞と考えている. 我々の検討は比較的揃った病態の早期のサを対象とし ていることもあり，大型と小型の移行や類上皮細胞の
生育過程を結論つけることはできなかった，類上皮細 胞はその微細構造の研究から, 布施ら゙によりリンパ 節を対象に肥満性類上皮細胞之萎縮性類上皮細胞に, Williams $ら^{5)} に よ り$ 脾, リンパ節を対象に暗調なAcell と淡明な B-cell に分類され，その形態と病態との 関連が論じられている，大型単核類上皮細胞はそれそ れの肥満性類上皮細胞招よび B-cell に分類されてい るものに近い細胞と考えている.

類上皮細胞の起源を微細構造面に求めることはでき なかった，肝肉芽腫結節の構成細胞の一つである組織 球様の細胞は, lysosome をるつことを最大の相異点と して類上皮細胞と異なる細胞である。組織球様の細胞 と類上皮細胞との間に移行形と考えられる細胞の存在 は観察できない，類上皮細胞の起源は一般に単球由来

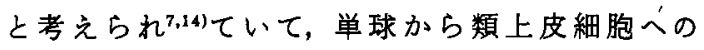
“transformation"に“phagocytosis”が主要因子の一つ と考充られている。にるかかわらず類上皮細胞が lysosomeなどの異物領食所見を欠くことは興味深い。

多核巨細胞の形成機序については，大型単核類上皮 細胞が fusionすることにより多核巨細胞が形成され

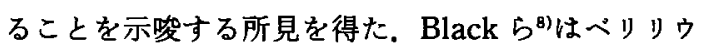
ムやジュニウムに過敏者の皮唐病変の研究から多核 巨細胞が単核類上皮細胞の fusionにより形成される ことを報告している。

旰に肉芽腫を形成する疾患はサと肝結核症がその大 半を占めることは既にのべた，通常臨床診断面から両 者を鑑別することは困難ではない.しかし結核症が軽 微であるとき，あるいは他藏器の結核病变が明瞭でな く肝が主病変となるとき ("primary" miliary tuberculosis of the liver) ${ }^{15)}$, 腹腔鏡下あるいは生検肝標本 に肉芽睡を観察することが診断の端緒となることがあ り，このとき両者を鑑別する必要が生じる，自験例を るとにサと肝結核症の臨床面を対比すると（Table 2, 3), サは発熱を欠くこと, ッ反応陰性が，肝結核症は血 沈促進が共通する所見である。発熱はサを除けば肝肉 芽腫症の多数例にみられる主要症状であり，肝肉芽腫 症の44\%が発熱を併ない（16）また遷延する不明発熱が その $9 \%$ に肝肉芽腫を認める17)という報告がある。発 熱を伴ならサる報告されてはいるが18)一般に少なく， 我々の検討からす発熱を併なわないことはサを示唆す る所見の一つ之考学られる。臨床検査成績の異常るま た軽微で䉼的価値をむつものはない，肉芽腫の数が 多いときALPの上昇, BSP 排泄試験の軽度遅延が報 告される゙が，自験例で肉芽庫の数の多寡と肝機能異 
常の程度との間に関連はない。

肝肉芽腫症は慢性肝病変へ進展する可能性(ブルセ ローシスから肝硬変へ進展した報告がある ${ }^{199}$ ) や黄㾝 の出現(慢性肝内䏣汁らっ滞を伴ならサの報告20)など) が論議されるが，我々が対象としたサにその様な症例 はない，むしろ反復腹腔鏡検查を行なった経過追跡例 で肉芽腫の减少あるいは消失を示した症例もある。サ の肝病变の予後については長期に亘る継時的な追跡が 必要となろら。

\section{結論}

サルコイドーシス24例を対象に肝肉芽腫につき病理 形態学的検討を加えた。

腹腔鏡視診下の針生検で, 肝肉芽畽は $83 \%$ の高率に 険出することができ，目標穿刺の有用性を強調した。

類上皮細胞はその微細構造より旺盛な生合成を営む 活動性細胞と考えられる.巨細胞は単核類上皮細胞の fusionにより形成される所見を得た。

症例検索の機会を頂いた大阪府立病院立花暉夫博士, 腹 腔鏡検査に御協力頂いた清永伍市，進士義剛，垣内義亨をは しめ大阪大学第 2 内科肝满研究室の諸先生に深謝します。

$$
\text { 文 献 }
$$

1) 立花睴夫, 荒武和彦, 村田吉郎, 他 : 各隇器のサル コイドーシス。消化器・肝病変. 最新医学 27 : 1286-1292, 1972

2）関 孝一: 肝の類上皮細胞肉芽嗹の超維細構造. 最新医学 $27: 1291-1292,1972$

3) Wanstrup J, Christensen HE: Sarcoidosis 1 Ultrastructural investigations on epithelioid cell granulomas. Acta Path et Microbiol Scandinav $66: 169-185,1966$

4) 三方淳男, 加納保之, 奥井津二, 他：サルコイド症 の病理. 肉芽隀結節の電顕像を中心にして。医療 $22: 637-644,1968$

5) Williams WJ, Erasmus DA, Jenkins D, et al: A comparative study of the ultrastructure and histochemistry of sarcoid and tuberculous granulomas. In : Fifth International Conference on Sarcoidosis, Edited by L Levinsky, F Macholda. Universita Karlova Praha, Praque, 1971, p115-120

6）布施裕輔, 平賀洋明, 浅川三男：サルコイド肉芽腫 の超構造. 1 . 肥満性類上皮細胞之萎縮性類上皮 細胞. 交通医学 $26: 311-326,1972$
7）布施裕輔，平賀洋明：サルコイド肉芽畽の超溦構 造. II. サルコイド類上皮細胞の起源. 交通医学 $27: 30-47,1973$

8) Black MM, Epstein WL: Formation of multinucleate giant cells in organized epithelioid cell granulomas. Amer J Path 74: 263 $-274,1974$

9) Klatskin G: Hepatic granulomata: Problems in interpretation. Mount Sinai J Med 44: 798 $-812,1977$

10) Irani SK, Dobbins WO: Hepatic granulomas: A review of 73 patients from one hospital and survey of the literature. J Clin Gastroenterol 1 : 131-143, 1979

11) Beck K: In: Farbatlas der Laparoskopie. 2. Aufl. FK Schattaner Berlag, Stuttgart, 1980, p148-156

12) Popper H, Schaffner F: Granulomatous diseases of the liver. In: Liver: Structure and Function, Mc Graw-Hill Book Co, New Yrok, 1957, p551-568

13) Alexander JF, Galambos JT: Granulomatous hepatitis. The usefulness of liver biopsy in the diagnosis of tuberculosis and sarcoidosis. Amer J Gastroenterol 59 : 23-30, 1973

14) Epstein WL, Kransnobrod $H$ : The origin of epithelioid cells in experimental granulomas of man. Lab Invest 18 : 190-195, 1968

15) Terry RB, Gunnar RM: "Primary" miliary tuberculosis of the liver. JAMA $164: 150-157$, 1957

16) Guckian JC, Perry JE: Granulomatous heptitis. An analysis of 63 cases and review of the liferature. Ann Intern Med 65 : 1081-1100, 1966

17) Simmon HB, Wolff SM: Granulomatous hepatitis and prolonged fever of unkonwn origin: A study of 13 patients. medicine 52 : 1-21, 1973

18) Nolan JP, Klatskin G: The fever of sarcoidosis. Ann Intern Med 61: 455-461, 1964

19) Mc Cullough NB, Eisele CW: Brucella hepatitis leading to cirrhosis of the liver. Arch Intern Med 88: 793-802, 1951

20) Rudzki C, Ishak KG, Zimmerman HJ : Chronic intrahepatic cholestasis of sarcoidosis. Amer J Med 59: 373-387, 1975 


\title{
Epithelioid cell granulomas of the liver in sarcoidosis -Laparoscopic and microscopic approaches-
}

\author{
Kouichi SeKI, Yuzo Minami, Masahiro Nishikawa, Sumio Kawata and \\ Seiichiro TARUI*
}

Liver biopsy was performed under laparoscopic observation of our 24 cases of sarcoidosis. Noncaseating epithelioid cell granulomas were histologically demonstrated in the liver biopsy specimens in 20 cases $(83 \%)$. Ten cases were examined by electron microscope. Ultrastructurally, epithelioid cell granulomas consisted of four cell type: epithelioid cells (large and small mononuclear epithelioid cells and multinuclear giant cells), histiocyte-like cells, lymphocytes and fibroblasts. Epithelioid cells seemed to be highly active cells with abundant cytoplasmic organelles: large amounts of Golgi apparatus, dense vacuoles of varing sizes and numerous mitochondria. It was peculiar not to find lysosomes in the cytoplam. Elongated cytoplasmic processes had developed an interdigitating cytoplasmic processes. Multinuclear giant cells were assumed to be formed by the fusion of large mononuclear epithelioid cells. Because of the presence of lysosomes in the cytoplasm, histiocyte-like cells were thought to be phagocytized type of highly active cells. Intermediate cells between histiocyte-like cells and epithelioid cells were not ultrastructurally evident in epithelioid cell granulomas in the liver.

* The Second Department of Internal Medicine, Osaka University Medical School (Osaka) 